\title{
Concurrent Staphylococcus aureus Septicaemia and Septic Arthritis in Dengue Infection
}

\author{
Deng Enfeksiyonunda Eş Zamanlı Staphylococcus aureus \\ Septisemi ve Septik Artrit
}

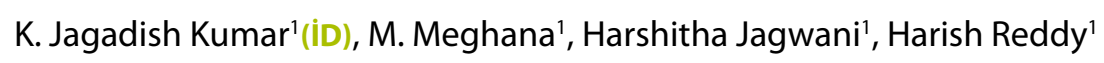 \\ ${ }^{\prime}$ Department of Pediatrics, JSS Academy of Higher Education and Research, Mysore, India
}

Cite this article as: Kumar KJ, Meghana M, Jagwani H, Reddy H. Concurrent Staphylococcus aureus septicaemia and septic arthritis in Dengue infection. J Pediatr Inf 2019;13(4):e172-e175.

\section{Abstract}

In tropical countries coinfections with dengue fever have been increasingly reported in various combinations. Usually fever lasts for 5-7 days in dengue illness. The possibility of co-infection is considered when fever persists beyond the anticipated period. Dengue fever usually manifests with significant severe arthralgia and myalgia, however dengue virus is not considered an arthritogenic virus. We report a child of dengue infection who presented with persisting fever with left lower limb pain diagnosed as concurrent staphylococcal septicaemia with septic arthritis.

Keywords: Dengue fever, frolonged fever, staphylococcal septicaemia, septic arthritis

\section{Introduction}

The clinical spectrum of dengue is highly variable, ranging from a mild flu-like syndrome to severe disease, with shock and haemorrhage (1). In tropical countries coinfections with dengue fever have been reported in various combinations $(2,3)$. Bacteraemia with dengue co-infection is rare $(4)$. Therefore timely diagnosis of coinfections is a challenge, if not coinfections may lead to life-threatening consequences. Dengue fever usually manifests with significant severe arthralgia and myalgia, however dengue virus is not considered an arthritogenic virus (5). We report a child of dengue infection who öz

Tropikal ülkelerde, Deng humması ile birlikte görülen enfeksiyon sayısı ve kombinasyon çeşitliliği son yıllarda artmış oranlarda bildirilmektedir. Deng hastalığında ateş genellikle 5-7 gün arasında sürmektedir. Ateş, öngörülen süreden daha uzun sürdüğünde bir koenfeksiyon ihtimali göz önünde tutulur. Deng virüsü artritojenik bir virüs olarak kabul edilmese de Deng humması kendini sıklıkla şiddetli artralji ve miyalji ile göstermektedir. Bu çalışmada biz, süregelen ateş ve alt ekstremite ağrısı ile başvuran ve stafilokok septisemi ve septik artrit tanısı alan bir çocuğu bildirdik.

Anahtar Kelimeler: Deng humması, uzamış ateş, stafilokok septisemi, septik artrit

presented with persisting fever with left lower limb pain diagnosed as concurrent staphylococcal septicaemia with septic arthritis and osteomyelitis.

\section{Case Report}

Previously health 9 year old boy presented with fever for 3 days and puffiness of face for 3 days. On examination he was febrile (temp $38.8^{\circ} \mathrm{C}$ ), PR 96/min, RR 24/min, BP 90/60 mmHg, capillary filling time (CFT) $<3$ seconds and oxygen saturation $99 \%$ at room air. He had flushing of the body with erythematous macular rashes more on the lower limbs, puffiness of face and bilateral conjunctival suffusion. Investigations and the course of the illness are dipicted in the Table 1 and Figure 1.

\footnotetext{
Correspondence Address / Yazışma Adresi

K. Jagadish Kumar

Deparment of Pediatrics,

JSS Academy of Higher Education and Research,

Mysore, India

E-mail: jagdishmandya@gmail.com
}

๑Copyright 2019 by Pediatric Infectious Diseases and Immunization Society. Available online at www.cocukenfeksiyon.org 


\begin{tabular}{|c|c|}
\hline Day 1 of admission & $\begin{array}{l}\text { Child had facial puffiness, flushing of the body with erythematous } \\
\text { macular rashes more on the lower limbs and bilateral conjunctival } \\
\text { suffusion. Therefore diagnosed as dengue infection. Dengue serology } \\
\text { was positive. }\end{array}$ \\
\hline $\begin{array}{l}\text { After } 48 \text { hours of } \\
\text { admission }\end{array}$ & $\begin{array}{l}\text { He was febrile, toxic, but unable to walk because of lower limb pain. } \\
\text { Vitals were stable. Examination revealed only painful movements of the } \\
\text { lower limbs. His CRP \& CK-NAC elevated. Co-infection with Chikungunya } \\
\text { suspected. Serology for Chikungunya sent and injection ceftriaxone } \\
\text { started on } 3^{\text {rd }} \text { day of admission. Elevated CK-NAC attributed for severe } \\
\text { myalgia of dengue infection. IgM ELISA for Chikungunya negative. }\end{array}$ \\
\hline Day 5 of admission & $\begin{array}{l}\text { He continues to have high fever and unable to walk. Vitals were stable. } \\
\text { Examination revealed painful, restriction of lower limb movements more } \\
\text { on left sidealong with left hipjoint tenderness. Inview ofjoint involvement, } \\
\text { differential diagnosis of left hip joint septic arthritis, transient synovitis, } \\
\text { acute leukemia and scrub typhus was made. His TLC and CRP elevated. } \\
\text { Blood peripheral smear did not reveal any blast cells. Sonography of hip } \\
\text { and knee joints was normal. Started on oral doxycycline and injection } \\
\text { linezolid. Skin traction of left lower limb applied. }\end{array}$ \\
\hline Day $9^{\text {th }}$ of admission & $\begin{array}{l}\text { He continues to have fever spikes but less intensity. Able to walk with } \\
\text { dragging left lower limb. Vitals were stable. Examination revealed } \\
\text { painful, mild restriction of left lower limb movements\&mild left hip } \\
\text { joint tenderness. His TLC and CRP elevated but decreased. Sonography } \\
\text { of hip and knee joints was normal. X-Ray both hips with pelvis normal. } \\
\text { Injection linezolid and ceftriaxone continued. Traction of left lower limb } \\
\text { continued. }\end{array}$ \\
\hline Day $14^{\text {th }}$ of admission & $\begin{array}{l}\text { Fever spikes decreased. Able to walk with mild dragging left lower limb. } \\
\text { Vitals were stable. Examination revealed, mild restriction of lower limb } \\
\text { movements on left side. MRI scan done after two weeks of admission } \\
\text { revealed osteomyelitis of pubic bone and septic arthritis of left hip joint. } \\
\text { Child was discharged on oral linezolid. }\end{array}$ \\
\hline
\end{tabular}

CRP: C-reactive protein, CK-NAC: Creatine Kinase, activated by N-Acetyl Cysteine, TLC: Total leucocyte count.

Figure 1. Sequence of events after admission.

\section{Discussion}

Co-infections with malaria, leptospirosis, typhoid fever, chikungunya virus as well as other organisms have been reported with dengue illness $(1,2,6)$. Bacterial co-infections in dengue fever have been increasingly reported (7). According to the review by Trunfio et al. $0.18 \%-7 \%$ of dengue infections are accompanied by concurrent bacteremia (8). Out of 9553 dengue cases, bacteremia was detected $29(0.3 \%)$ of patients and the commonest bacteria being Staphylococcus aureus (48.3\%). Concurrent bacteremia (positive bacterial blood culture within 72 hours of admission) was diagnosed in $62.1 \%$ cases and S. aureus was the commonest organism (7). Araújo et al. reported 14 year old boy initially diagnosed with classical dengue fever, who subsequently developed a fatal septic shock caused by S. aureus (1). Among 5000 cases with symptomatic dengue infection in Taiwan, seven cases had bacteremia (9). Lee et al. observed bacteremia in $5.5 \%$ of the patients among 774 patients presenting with DHF [Dengue Haemorrhagic Fever]/DSS [Dengue shock syndrome] (9). Out of 114 dengue fever, two grew $S$. aureus in a study from Delhi (10). A study from Singapore observed cluster of S. aureus and dengue -co-infection and all of them had skin and soft tissue infection (4). Our dengue illness child had concurrent S. aureus bactremia and presented as lower limb pain due to septic arthritis and osteomyelitis. In view of joint involvement, differential diagnosis of left hip joint septic arthritis, transient 
Table 1. Investigations

\begin{tabular}{|c|c|c|c|c|c|c|c|c|}
\hline Investigations & Admission & $3^{\text {rd day }}$ & $4^{\text {th }}$ day & $5^{\text {th }}$ day & $6^{\text {th }}$ day & $7^{\text {th }}$ day & $9^{\text {th }}$ day & $11^{\text {th }}$ day \\
\hline $\begin{array}{l}\text { Hemoglobin } \\
(\mathrm{g} / \mathrm{dL})\end{array}$ & 10.9 & 9.6 & 9 & 8.8 & 8 & & 8.7 & 8.4 \\
\hline PCV (\%) & 31.9 & 29.2 & 26.2 & 25.4 & 23 & & 27 & 26 \\
\hline TLC (cells/mm³) & & & & 15.900 & & 16.200 & 13.090 & 16.370 \\
\hline$N, L, E, B, M(\%)$ & & & & $53,40,3,3,1$ & & $48,47,1,3,1$ & $46,47,1,5,1$ & $68,26,1,4,1$ \\
\hline CRP (mg/L) & & 115.7 & & 152 & & 85.5 & 49.4 & 42.7 \\
\hline $\begin{array}{l}\text { Platelet count } \\
\left.\text { (lakhs } / \mathrm{mm}^{3}\right)\end{array}$ & 1.23 & 1.37 & 1.41 & 1.65 & 1.57 & 1.3 & 1.27 & 2.16 \\
\hline ESR $\mathrm{mm} 1^{\text {st }} \mathrm{hr}$ & & & & & & 95 & 10 & \\
\hline $\begin{array}{l}\text { SGOT (U/L) } \\
\text { SGPT (U/L) }\end{array}$ & $\begin{array}{c}45 \\
110 \\
\end{array}$ & & & & & & & \\
\hline $\begin{array}{l}\text { CK-NAC } \\
(\mathrm{N}=0-109 \mathrm{U} / \mathrm{L})\end{array}$ & & 200 & & & & & 56 & \\
\hline $\begin{array}{l}\text { Sonography } \\
\text { abdomen }\end{array}$ & & & $\begin{array}{c}\text { Gall bladder wall } \\
\text { edema and wall } \\
\text { thickness of } \\
6 \mathrm{~mm}\end{array}$ & $\begin{array}{c}\text { Gall bladder wall } \\
\text { edema and wall } \\
\text { thickness of } 6 \\
\text { mm, ascites }\end{array}$ & & & & \\
\hline $\begin{array}{l}\text { Sonography hip } \\
\text { and knee joints }\end{array}$ & & & & Normal & & Normal & Normal & \\
\hline $\begin{array}{l}\text { X-Ray both hips } \\
\text { with pelvis }\end{array}$ & & & & & & Normal & & \\
\hline \multicolumn{9}{|c|}{$\begin{array}{l}\text { Kidney functions and chest X-Ray normal. } \\
\text { Serology for Dengue: -Mac Capture ELISA for IgM positive, ELISA NS } 1 \text { Antigen positive, } \\
\text { Peripheral smear for malarial parasite, weil -felix and widal test negative } \\
\text { IgM ELISA for Chikungunya negative. } \\
\text { Blood culture grew Staphylococcus aureus sensitive to oxacillin, linezolid, vancomycin, clindamycin, daptomycin, erythromycin and resistant to penicillin-G, ciprofloxacin. } \\
\text { MRI scan done after two weeks of admission revealed osteomyelitis of pubic bone and septic arthritis of left hip joint. } \\
\text { PCV: Packed cell volume, TLC: Total leucocyte count, N: Neutrophil, L: Lymphocyte, B: Basophils, ESR: Erythrocyte sedimentation rate, CRP: C-reactive protein, CK-NAC: Creatine kinase, } \\
\text { activated by N-Acetyl Cysteine, SGOT: Serum glutamic-oxaloacetic transaminase, SGPT: Serum glutamic pyruvic transaminase. }\end{array}$} \\
\hline
\end{tabular}

synovitis, acute leukemia and scrub typhus was made. Dengue infection is associated with severe arthralgia and myalgia (5). Dengue virus is not considered an arthritogenic virus. But Chikungunya virus can cause arthritis $(5,6)$. Therefore co-infection with Chikungunya was suspected in view of elevated C-reactive protein (CRP), but serology for Chikungunya was negative. Scrub typhus can present with myalgias, however his weil-felix test was negative. His peripheral blood smear did not show any blast cells. Our child continues to have fever for more than 7 days, had elevated leucocyte count and CRP with left hip joint tendreness. Therefore septic arthritis was kept as diagnosis and injection linezolid was started inspite of normal sonography of the joints. However MRI [Magnetic Resonance Imaging] scan done after two weeks of admission revealed osteomyelitis of pubic bone and septic arthritis of left hip joint.

Thein et al. observed that patients with dengue and concurrent bacteremia are more likely to be critically ill, have DSS, higher neutrophil count, lower lymphocyte count, hemo- concentration with thrombocytopenia at admission (7). Lee et al. concluded that patients with prolonged fever, higher frequencies of acute renal failure, gastrointestinal bleeding, altered consciousness, unusual dengue manifestations and DSS should be assessed for possible co-infection (9). However our child was not critically ill, never had bleeding tendencies/severe thrombocytopenia or kidney injury. Co-infection has been shown to worsen the outcome of dengue infection (9). Bacteremia seems to accounts for $14.3 \%$ to $44.4 \%$ of dengue-related deaths among various studies (7). Hypotheses on the pathogenesis of concurrent bacteremia in patients with dengue include disintegration of endothelial cells by antibodies against dengue non structural protein and/or relative immunosuppression. The disintegration of endothelial cells may allow the entry of bacteria into the bloodstream leading on to bacteremia $(1,7)$. In Dengue, fever is the initial symptom which would camouflage any septicaemia (10). The possibility of co-infection was considered when fever persisted beyond the anticipated period characteristic of dengue fever. In dengue 
illness, usually fever lasts for 5-7 days. Lee et al. opined that patients with DHF/DSS who also have prolonged fever ( $>5$ days) are at high risk for concurrent bacteremia. In our child fever spikes continued for more than 10 days. As the mortality is very high in bacteremia associated with dengue-infection collection of blood cultures and empiric antibiotic therapy may be considered in patients who are critically ill (7).

\section{Conclusion}

While treating dengue cases, careful attention should be given to the natural clinical course and high index of suspicion is necessary to identify concurrent bacteremia so that the morbidity and mortality can be decreased.

Informed Consent: Informed consent taken.

Peer-review: Externally peer-reviewed.

Author Contributions: Concept - KJK, MM, HJ; Design - KJK, MM, HJ; Supervision - KJK; Data Collection and/or Processing - HJ, HR; Analysis and/or Interpretation - HJ, HR; Literature Review - HJ, HR; Writing - KJK, HR; Critical Review - KJK.

Conflict of Interest: The authors have not reported a conflict of interest.

Financial Disclosure: There is no financial support in this study.

\section{References}

1. Araujo SA, Moreira DR, Veloso JMR, Silva JO, Barros VL, Nobre V. Fatal staphylococcal infection following classic dengue fever. Am J Trop Med Hyg 2010;83:679-82. [CrossRef].

2. Pancharoen $C$, Thisyakorn U. Coinfections in dengue patients. Pediatr Infect Dis J 1998; 17:81-2. [CrossRef]"

3. Kumar KJ, Chavan A, Anitha C, et al. Concurrent dengue infection and Pseudomonas aeruginosa septicemia with classical_ecthyma gangrenosum in an infant. J Pediatr Infect Dis 2014;9:197. [CrossRef].

4. Chai $L Y$, Lim PL, Lee CC, Hsu $L Y$, Teoh YL, Lye DC, et al. Cluster of Staphylococcus aureus and dengue co-infection in Singapore. Ann Acad Med Singapore 2007;36:847-50.

5. Jayamali WD, Herath HMMTB, Kulatunga A. A young female presenting with unilateral sacroiliitis following denque virus infection: a case report. J Med Case Report 2017;11:307. [CrossRef].

6. Kumar KJ, Manjunath VG, Shailashree M, Girish GN. Coinfection of dengue and chikungunya in a child-a case report. J Indian Med Assoc 2012;110:749-52.

7. Thein TL, Ng EL, Yeang MS, Leo YS, Lye DC. Risk factors for concurrent bacteremia in adult patients with dengue. J Microbiol Immunol Infect 2017;50:314-20. [CrossRef],

8. Trunfio $M$, Savoldi A, Viganò $O$, d'Arminio Monforte A. Bacterial coinfections in dengue virus disease: what we know and what is still obscure about an emerging concern. Infection 2017;45:1-10. ['[CrossRef],

9. Lee IK, Liu JW, Yang KD. Clinical characteristics and risk factors for concurrent bacteremia in adults with dengue hemorrhagic fever. Am J Trop Med Hyg 2005;72:221-6. [CrossRef].

10. Arya SC, Agarwal N. Concurrent dengue fever and bacterial septicemia during the 2008 dengue outbreak in Delhi. Dengue Bulletin 2008;32:226-7. 